\title{
THE VALUE OF CUSTOMER SERVICE AS A FUNDAMENTAL DIMENSION OF THE BUSINESS MODEL OF COMPANIES IN THE TFL SECTOR, FOCUSED ON SALES REVENUE
}

\author{
Katarzyna Dębkowska \\ Faculty of Management, Bialystok University of Technology, 2 Tarasiuka, 16-001 Kleosin, Poland \\ E-mail: k.debkowska@pb.edu.pl
}

\begin{abstract}
This article aims to examine the relationship between the fundamental dimension of the business model and the amount of sales revenue. The study was conducted using data from the TFL sector companies. The research task was performed with the use of statistical methods. In order to identify services significantly differentiating the revenues of companies from the researched sector, non-parametric MannWhitney test was used. The article also makes an attempt on predicting, with the use of regression trees, the amount of sales revenues, depending on the type of the offered service. The study allowed for the adoption of a revised research hypothesis stating that a properly selected set of services in the business model translates into higher revenues from the sale of the businesses from the TFL sector.
\end{abstract}

Keywords: business models, the value of customer service, sales revenue, TFL sector, logistics services, statistical methods.

JEL Classification: M21; R410.

\section{Introduction}

The business model is a key element of the strategy of a company (Chesbrough, Rosenbloom 2002; Casadesus-Masanell, Ricart 2010). The theories in the field of organization and management mention the business model as the term describing the overall concept of the activity of a company, whereas its description is schematic and parameterized. Business models have their components, referred to as the dimensions of a business model (Mahadevan 2000; Baden-Fuller, Morgan 2010; Jabłoński 2013). The dimensions of a business model that are most frequently cited in the literature are: the value of a service to a customer, enterprise resources, chain of value, and the supported market segments (Johnson et al. 2008).

The manner in which a company operates in these dimensions determines the specifics of the business model. Due to the fact that each company builds the dimensions of its model differently, there is a variety of business models, even among companies operating in the same industry. However, every business model should focus on activities that provide benefits for the customer, and ensure profit for the company (Afuah 2004; Chesbrough, Rosenbloom 2002; Nenonen, Storbacka 2010; Teece 2010).

The TFL (transport-forwarding-logistics) sector companies operate in changing conditions and need to adjust the offered services to the customers' needs in order to provide them with the greatest benefit.
The TFL sector is developing rapidly, more and more companies emerge in this sector, and this causes an increase in competition in the logistics market. Therefore, such development of the company, which will provide it with a competitive advantage is an important issue (McGrath 2012; Casadesus-Masanell, Zhu 2013). Thus a question arises: what set of logistics services will provide benefits to the customer, and at the same time will translate into the desired financial results, including a correspondingly high sales revenues.

This article aims to examine the relationship between the fundamental dimension of the business model, which is the value of customer service and the amount of sales revenue.

The study was conducted using data from the TFL sector companies which participated in the 20th edition of the Ranking of the TFL Sector Companies operating in Poland.

The implementation of the research objective was carried out using the statistical methods. In the first step, the identification of logistics services significantly differentiating sales revenues of companies of the researched sector was carried out. For this purpose a non-parametric Mann-Whitney $U$ test was used. In the next step, a prediction of sales revenues of companies in the TFL sector, depending on the type of service offered, was carried out. In the implementation of this research task, one of the methods of multivariate statistics, which are regression trees, was used. 


\section{The basic dimensions of the business model of TFL companies}

The TFL sector (transport-forwarding-logistics) is developing very dynamically. It has to do with the increase in demand for logistics services, whose customers are often industrial companies. More and more companies are looking for logistics service providers, whom they entrust with the implementation of a variety of services, ranging from the "simple" services up to comprehensive logistics services (Arnold et al. 2008; Radziejowska 2011). Due to the considerable range of cooperative and commercial relations of enterprises in the sector of TFL, the functioning and activities of TFL enterprises is strictly dependent on external factors such as globalization, hypercompetition, development of new technologies in the field of IT and energetics (Gudehus, Kotzab 2012; Zysińska 2013a). Effective functioning in such an environment should be supported by a properly constructed business model.

In the literature, there is no one joint and deepened concept regarding the business models for the TFL sector. Individual authors have performed interesting classifications of the business models in the TFL sector, as well as summaries regarding the service providers and the modern services within the TFL sector (Gołębiowski et al. 2008; Brdulak 2002; Grant 2010; Rydzkowski 2011; Blaik et al. 2013).

When reviewing the literature on business models in the TFL sector it is possible to distinguish five types of such models: provider of standard TFL services, traditional operator of TFL services, TFL niche services operator, leading operator of TFL services, integrator of TFL services. (Zysińska 2013a; Blanchard 2008; Bamford 2010). The providers of logistic services, therefore form certain classes of business models, ranging from simple models to classes of new models, often based on cooperation (Burdzik, Cieśla 2006; Gattorna 1998).

The demand for specialized and professional logistic service results in the development of logistics companies, offering an increasingly broad package of logistics services, whose scope goes far beyond the standard services such as transportation, freight forwarding, warehousing. Companies are trying to change the business model of the provider of standard TFL services to the model of the operator of TFL services. Logistics operators act as companies with a complex structure, in addition to basic services also offering storage and handling of inventories, transportation and handling of cargo, all kinds of marketing services, financial services related to the execution of contracts (Rydzkowski 2004).

A very important dimension of the business model is, therefore, the value of customer service. This dimension can be understood more broadly, both according to P. Kothler's marketing approach, related to the creation of a competitive advantage, as well as in the traditional sense, i.e. purely transactional. The value consists of both tangible and intangible benefits, derived from TFL services. A significant element, co-creating the value of a TFL service for the customer is called added value, which means the involvement in the creation of value for the end user of the goods delivered. The elements comprising value in the assessment of the clients of TFL services are the financial and nonfinancial benefits, such as, for example: time, flexibility, punctuality and security of supply, individualized approach, comprehensive services, the ability to quickly communicate with customers with the use of IT systems (Zysińska 2013b). The article focused mainly on the value of services for customers, as offering an adequate number of properly selected services.

\section{Research methodology}

This article attempts to examine the relationship between the basic dimension of the business mod$\mathrm{el}$, which is the value of services for customers, and the amount of sale revenue of enterprises in the sector of TFL services. The research hypothesis revised in the article, adopted the following form: a properly selected set of services in a business model translates into higher sale revenues of enterprises in the sector of TFL services.

The study included 70 companies from the TFL sector, which joined the 20th edition of the Ranking of Companies in the Sector of TFL services. Considering the available data, an analysis has been performed of one of the dimensions of the business models, namely the value of the services to the customer. The assessment of this dimension was carried out by checking the number and types of services offered. The research question was whether the number and type of the services provided affects the differences in sales revenue obtained by the surveyed companies.

Revenues from sales (in thousand PLN) were adopted in the study as the explanatory variable. The explanatory variables include 19 services listed in the Ranking with regards to the presence or absence of which the companies participating in the Ranking were examined. Thus, the dependent variable is a measurable continuous variable, and 
the explanatory variables are dichotomous variables. The type of variables to a large extent determines the selection of appropriate methods for static analysis. The article uses a diverse set of static methods, such as basic descriptive statistics, measures of correlation, nonparametric tests, and one of the methods of multivariate statistical analysis - regression trees.

Analysing the distributions of income from sales and the number of offered services in the surveyed enterprises, measures of descriptive statistics were used (mean, median, coefficient of variation, asymmetry factor), which allowed for indication of central tendency, variation and asymmetry of the analysed variables. Apart from that, using measures of correlation (Pearson's linear correlation coefficient) in a numerical manner, strength and direction of the relationship between sales revenue and the place occupied in the Ranking, and the relationship between sales revenue and the number of services offered were presented.

In order to identify the services which significantly affect the average level of sales revenues, 19 null hypotheses on the lack of significant difference in average level of sales revenues in the companies offering or not offering the service were presented. Verification of hypotheses was performed using the nonparametric Mann-Whitney $U$ test (Wilcoxon 1945; Mann, Whitney 1947). As a result of the performed tests, 14 of the 19 hypotheses were rejected, which means that in the case of 14 services offered there are significant differences in average sales revenues of companies in the TFL sector.

The choice of this test was based on the lack of compliance with the normal distribution of the variable of the sales revenue. The Mann-Whitney $\mathrm{U}$ test is an alternative to the t-test and is used when the assumption of the normal distribution of the population is not fulfilled (Corder, Foreman 2009; Herrnstein et al. 1976; Lehmann 2006). It is only slightly weaker than the t-test, and much stronger than the test of the Wald-Wolfowitz series (Aczel 2000).

In the test calculation procedure samples are combined and observations arranged from the smallest to the largest. To equal values the arithmetic mean of the ranks (position in the ranking) of these values is allocated, then all the ranks of observations from one population are added up and this population is marked as 1 . The sum of ranks is denoted by $R_{1}$. Statistics of the Mann-Whitney $\mathrm{U}$ test is presented by the formula:

$$
\mathrm{U}=n_{1} n_{2}+\frac{n_{1}\left(n_{1}+1\right)}{2}-R_{1},
$$

where: $n_{1}-$ size of the population $1 ; n_{2}-$ size of the population 2 .

The $\mathrm{U}$ statistics is a measure of the difference between the ranks of two tests. Large or small values of these statistics provide evidence of a difference between the two populations. If we assume that differences between populations exist only in the position, then the big or small values of statistics constitute evidence of the existence of the difference in the position of the mean value of the population.

The studies predicted the average level of sales revenues of companies from the TFL sector, depending on the set of the offered services. Here, the method of multivariate statistics - regression trees was useful. We are dealing with regression in the cases, where we want to learn the value of a continuous variable, basing on the knowledge of the value of one or more continuous predictor variables and, possibly, categorical variables.

Regression Trees are a family of statistical methods, which, with the use of diagrams, sequentially divide the tested data space into classes (subspaces) with similar characteristics. The history of regression trees began with the appearance of the book by presenting the CART (Classification and Regression Breiman et al. (1993) Tree) model used even today. Another major publication was the book by Quinlan, dealing with the construction and implementation of the so-called $\mathrm{C} 4$ algorithm, which is a modification of the algorithm proposed by Breiman (Breiman et al. 1993; Quinlan 1993; Lewis 2000).

Regression Trees are used in many fields of science. This method can be encountered in marketing research related to the acquisition of new customers, study the causes of disloyalty of consumers (churn analysis), in the detection of fraud as well as in the analysis of survey data.

Regression Trees can be simply displayed graphically, making them easier to interpret than purely numerical results. Regression Trees can be, and sometimes are, quite complex. However, graphic procedures facilitate the interpretation of even complicated solutions (Breiman et al. 1993; Loh, Shih 1997).

The created tree is not only a predictive but also a descriptive model, allowing to describe and present patterns in the surveyed population (Rokach, Maimon 2008). The process of building the tree is done using a recursive division (Kotsiantis 2007), where in each successive node different independent variables can be used for analysis. At each stage all the predictors (variables) are analysed, and the one which offers the best division of 
the node, i.e., the one that allows for obtaining the most homogeneous subsets, is selected (Loh, Shih 1997).

In the article, the income from the sale of enterprises from the TFL sector is the measurable (quantitative) dependent variable. As explanatory variables (predictors), affecting the sales revenues 14 logistics service with the variants: occurs, does not occur, were used.

\section{Findings and discussion}

According to the conducted statistical analysis of the variable of sales revenues, it is characterized by a very strong differentiation (the coefficient of variation equal to $140.8 \%$ ) and a very strong rightsided asymmetry (asymmetry coefficient equal to 3.7). Thus, we observe significant differences in the revenues achieved by the surveyed companies, and the vast majority of companies achieves revenues below the average level (mean equal to PLN 218647.4 thousand). Noteworthy is the fact that half of the companies achieve revenues not higher than PLN 115593.5 thousand (Table 1).

The structure of enterprises due to the sales revenue is shown in Figure 1. After dividing enterprises due to the sales revenue of class income we can see that every fifth company achieved revenues of not more than PLN 50000 thousand. In the group of companies with the highest revenues, over PLN 500000 thousand is 9\% of enterprises.

Table 1. Descriptive statistics variable sales revenues (Source: own calculations based on data from the ranking of companies in the sector TFL)

\begin{tabular}{l|c|c|c|c}
\hline Variable & Mean & Median & $\begin{array}{c}\text { Coefficient } \\
\text { of } \\
\text { variation }\end{array}$ & $\begin{array}{c}\text { Asymmetry } \\
\text { coefficient }\end{array}$ \\
\hline $\begin{array}{l}\text { Sales } \\
\text { revenues }\end{array}$ & 218647.4 & 115593.5 & $140.8 \%$ & 3.7 \\
\hline
\end{tabular}

The first places in the ranking are occupied by companies with the highest sales revenues in excess of PLN 500000 thousand, and the last places in the ranking are occupied by companies with revenues of less than PLN 20000 thousand. The correlation between the place in the ranking and the revenues is very strong (Pearson's correlation coefficient amounts to -0.90 ), but the sales revenues were not the only factor deciding about the place in the ranking.

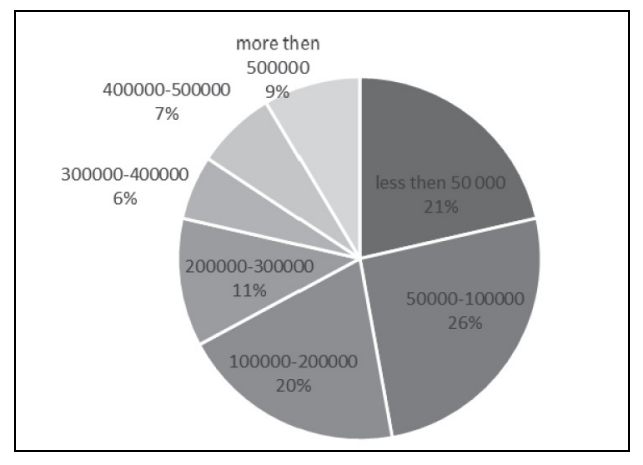

Fig. 1. The structure of enterprises due to the sales revenue (Source: own calculations based on data from the ranking of companies in the sector TFL)

Companies have pointed to the type and number of the services provided as a result of their activity. From the directory of 19 services, the analysed companies indicated the ones that occur in their business models. The most popular services are the typical TFL services - forwarding $(94.29 \%$ of responses), transport ( $91.43 \%$ of responses), and storage ( $74.29 \%$ of responses). The least frequently indicated services are the rolling stock services (7.14\% of responses), maintenance of railway sidings and other railway infrastructure $(11.43 \%$ of responses), and courier services (12.86\% of responses) (Fig. 2).

The surveyed companies offer from one to eighteen services. On average, one company accounts for about 9 services (average equal to 8.9), while half of the companies offer no less than 8 services (median). The companies from the sector of TFL services are moderately diverse in terms of the number of the services provided (Table 2).

Table 2. Descriptive statistics variable number of services (Source: own calculations based on data from the ranking of companies in the sector TFL)

\begin{tabular}{l|c|c|c}
\hline Variable & Mean & Median & $\begin{array}{c}\text { Coefficient } \\
\text { of variation }\end{array}$ \\
\hline Number of services & 8.9 & 8 & $54.3 \%$ \\
\hline
\end{tabular}

To investigate whether there is a correlation between the number of services provided and the sales revenues, the Person's correlation factor was determined to yield a statistically significant, moderate positive correlation (coefficient equal to 0.35). By calculating the determination coefficient, we can say that in $12.3 \%$ the size of revenues is affected by the number of services provided. 


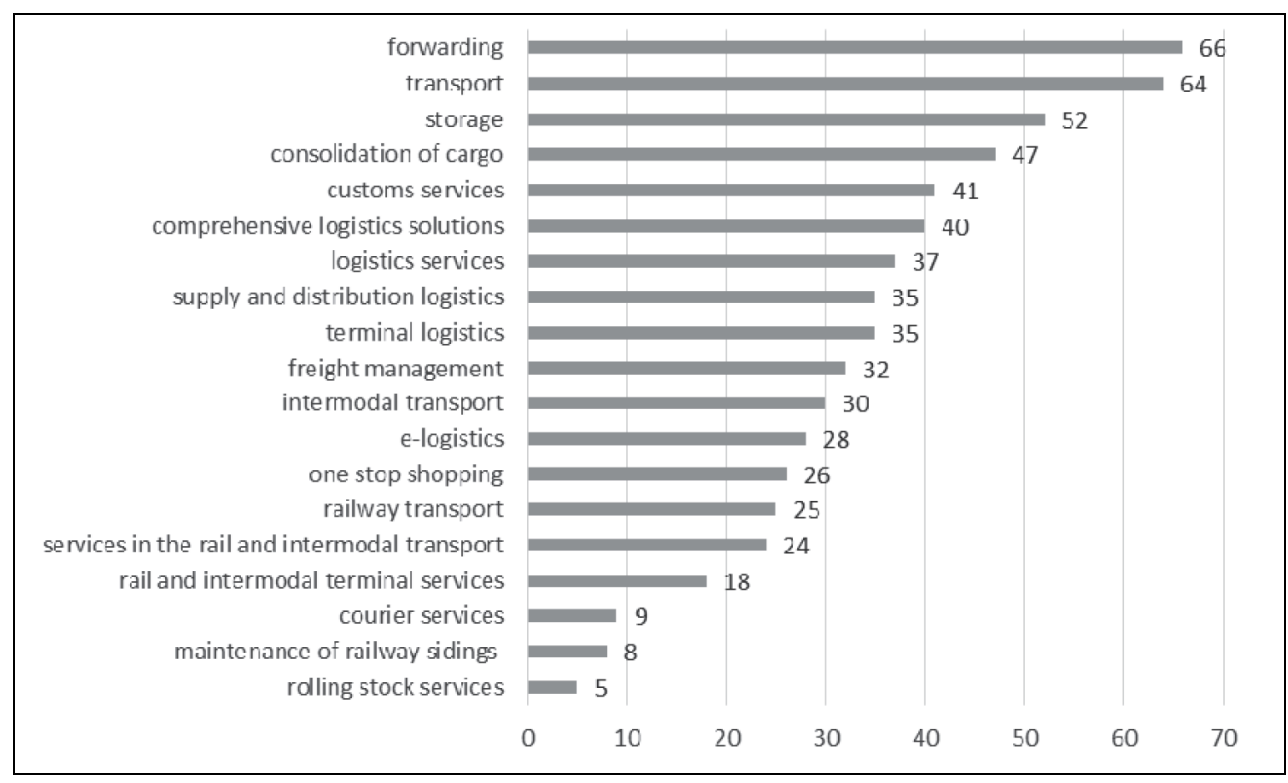

Fig. 2. Frequency of occurrence individual services in the surveyed sector enterprises TFL (Source: own calculations based on data from the ranking of companies in the sector TFL)

A fact worthy of note is which services significantly differentiate the average revenue of the companies from the TFL services sector. To this end, a non-parametric Mann-Whitney U test was performed, which analyses the equality of the average value of two populations. It is an alternative to the t-test for two samples and we use it when the assumption of normality of the distribution of the population is not fulfilled. Using the MannWhitney U test, it was possible to analyse the differences in the average sales revenues of companies using or not using the service.

The test results indicate that that out 19 services, until as many as 14 significantly differentiate the average sales revenues (Table 3 ). Significantly higher sales revenues are achieved by the companies using the following services: management of freight, logistics services, terminal logistics, supply and distribution logistics, comprehensive logistics solutions, e-logistics, one-stop shopping, rail and intermodal transport services, intermodal transport, rail and intermodal terminal services, rolling stock services. Significantly higher average sales revenues are achieved by the companies not having in their offer the typical logistics services such as transportation and logistics.

In the next step of the analysis an attempt was made to predict the sales revenues of companies from the TFL sector, depending on the type of services offered. For this purpose, a regression tree was used, where the sales revenues were adopted as the dependent variable. The method of regression trees allowed to discover the value of sales revenues, depending on categorical predictors, represented by the services selected with the use of the Mann-Whintney U test, as the ones significantly differentiating the sales revenues. One of the elements of the analysis of regression trees is the assessment of the validity of the predictors.

This allowed the reduction of the number of services taken into account by almost half, because 8 services were characterized by low importance (less than 0.5). As a result, the following were adopted to the regression tree as categorical predictors: supply and distribution logistics, rail and intermodal transport services, logistics services, rail and intermodal terminal services, one stop shopping, e-logistics (Fig. 3).

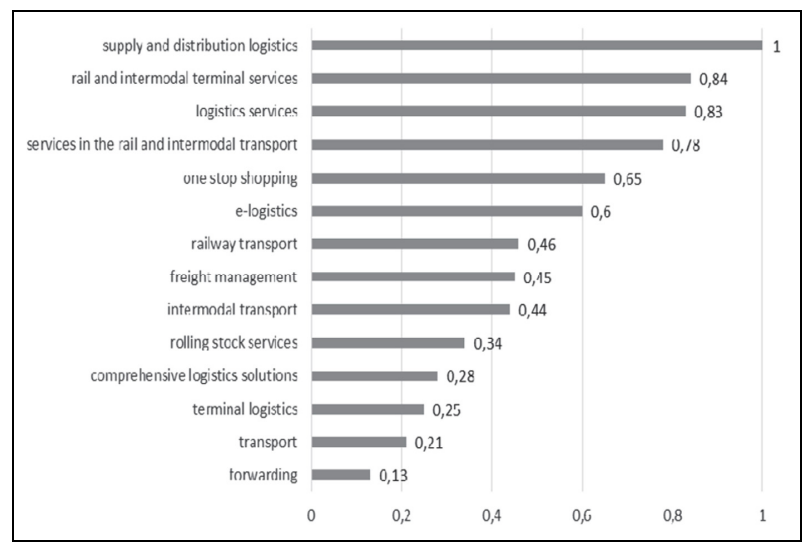

Fig. 3. The importance of services by regression trees (Source: own calculations based on data from the ranking of companies in the sector TFL) 
Table 3. The significance of differences in average sales revenues of companies from the TFL sector (Source: own calculations based on data from the ranking of companies in the sector TFL)

\begin{tabular}{|c|c|c|c|c|}
\hline Service & $\begin{array}{l}\text { Test U } \\
\text { p-value }\end{array}$ & $\begin{array}{c}\text { Average sales revenues } \\
\text { of companies not using } \\
\text { the service }\end{array}$ & $\begin{array}{c}\text { Average sales revenues } \\
\text { of companies using } \\
\text { the service }\end{array}$ & $\begin{array}{c}\text { The difference } \\
\text { between averages }\end{array}$ \\
\hline e-logistics & $\begin{array}{l}4.681 \\
0.000 \\
\end{array}$ & 114930.80 & 415208.00 & 300277.20 \\
\hline one stop shopping & $\begin{array}{l}4.248 \\
0.000 \\
\end{array}$ & 125593.00 & 420262.50 & 294669.50 \\
\hline rolling stock services & $\begin{array}{c}-1.961 \\
0.050 \\
\end{array}$ & 215265.40 & 492132.80 & 276867.40 \\
\hline $\begin{array}{l}\text { rail and intermodal terminal } \\
\text { services }\end{array}$ & $\begin{array}{l}3.071 \\
0.002 \\
\end{array}$ & 171925.30 & 417378.10 & 245452.80 \\
\hline $\begin{array}{l}\text { comprehensive logistics } \\
\text { solutions }\end{array}$ & $\begin{array}{l}3.424 \\
0.001 \\
\end{array}$ & 123918.70 & 318383.90 & 194465.20 \\
\hline freight management & $\begin{array}{l}3.236 \\
0.001 \\
\end{array}$ & 153613.40 & 331737.70 & 178124.30 \\
\hline intermodal transport & $\begin{array}{l}3.163 \\
0.002\end{array}$ & 160322.30 & 334667.60 & 174345.30 \\
\hline terminal logistics & $\begin{array}{l}3.019 \\
0.003\end{array}$ & 155375.20 & 314708.20 & 159333.00 \\
\hline consolidation of cargo & $\begin{array}{l}1.851 \\
0.064\end{array}$ & 134375.60 & 284303.80 & 149928.20 \\
\hline railway transport & $\begin{array}{l}2.047 \\
0.041 \\
\end{array}$ & 182382.00 & 329829.10 & 147447.10 \\
\hline logistics services & $\begin{array}{l}3.153 \\
0.002 \\
\end{array}$ & 163213.70 & 299104.50 & 135890.80 \\
\hline $\begin{array}{l}\text { services in the rail and } \\
\text { intermodal transport }\end{array}$ & $\begin{array}{l}2.691 \\
0.007 \\
\end{array}$ & 190456.40 & 320496.80 & 130040.40 \\
\hline storage & $\begin{array}{l}1.727 \\
0.084 \\
\end{array}$ & 154675.40 & 262860.80 & 108185.40 \\
\hline $\begin{array}{l}\text { supply and distribution } \\
\text { logistics }\end{array}$ & $\begin{array}{c}-3.232 \\
0.001 \\
\end{array}$ & 181183.50 & 288899.90 & 107716.40 \\
\hline customs services & $\begin{array}{l}1.586 \\
0.113 \\
\end{array}$ & 179002.90 & 274678.90 & 95676.00 \\
\hline $\begin{array}{l}\text { maintenance of railway } \\
\text { sidings (and other rail } \\
\text { infrastructure) }\end{array}$ & $\begin{array}{c}-1.541 \\
0.123\end{array}$ & 231922.60 & 259214.40 & 27291.80 \\
\hline courier services & $\begin{array}{c}-0.877 \\
0.380 \\
\end{array}$ & 235057.00 & 234937.70 & -119.30 \\
\hline transport & $\begin{array}{c}-2.004 \\
0.045\end{array}$ & 439799.50 & 215845.60 & -223953.90 \\
\hline forwarding & $\begin{array}{c}-2.138 \\
0.033 \\
\end{array}$ & 573505.30 & 214528.70 & -358976.60 \\
\hline
\end{tabular}

The resulting regression tree was characterized by 5 end nodes with a number from 1 to 28 . Each end node contained a predicted value of the average sales revenues determined on the basis of the occurrence of a particular service (Fig. 4). For further interpretation, the terminal nodes characterized by a number greater than 5 were selected.

The expected highest amount of average revenues from sales in the amount of PLN 385531 thousand was determined for companies that have e-logistics, rail intermodal terminal services, supply and distribution logistics and logistics services in their offer. Rather high average sales revenues at the level of PLN 267850 thousand are envisaged for companies having the three following services in its offer: e-logistics, logistic services and onestop shopping. If companies include the services of rail and intermodal transport, then the expected average level of sales revenues in their case is PLN 182122 thousand. The average revenues at the level of PLN 130432 thousand will be achieved by the companies mainly engaged in e-logistics and logistics services. 


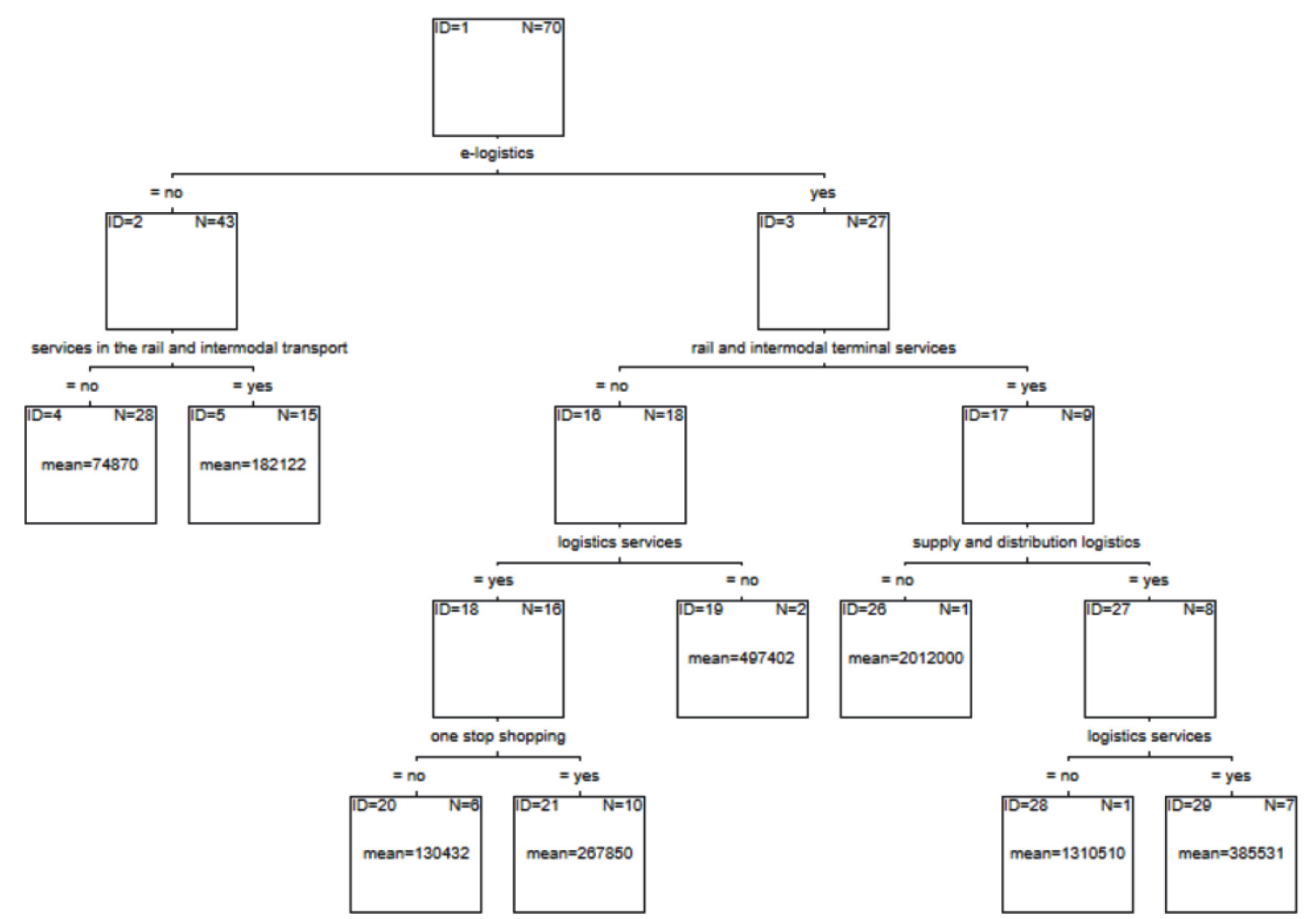

Fig. 4. Regression tree for prediction of average revenues from sales in relation to the type of services used (Source: own calculations based on data from the ranking of companies in the sector TFL)

\section{Conclusions}

The conducted study of the TFL sector companies shows that a properly selected set of offered logistics services is a very important dimension of the business model of the company, which is the value of the service for the customer. The offered services should adapt to the needs of customers and to external factors, in which the firm operates. A proper set of the offered services gives the company a competitive advantage in the market of logistics services.

The article shows, on the basis of empirical studies, that offering certain services significantly increases the average sales revenue of enterprises from the TFL sector. These services include: elogistics, one-stop shopping, rolling stock services, rail and intermodal terminal services.

The use of statistical methods, in particular regression trees, allowed for the prediction of the average sales revenues for the company applying the appropriate set of logistics services. The chance to have the highest revenue have the companies, which offer both e-logistics and rail and intermodal terminal services. The companies that offer onestop shopping, e-logistics and logistics services can also count on a fairly high income from sales. On the other hand, offering only forwarding as a logis- tics services classifies the company as one of those, which on average achieve the lowest income.

The presented results of the research regard the business model dimension which is the value for the customer. This dimension in the article was conceived as a number and set of the TFL logistics services offered to the customer. Further research will be continued with regard to the wider understanding of the value of services for the customer and studying its impact on the financial condition of enterprises in the TFL sector.

\section{References}

Aczel, A. D. 2000. Statistics in the management. Warsaw: Wydawnictwo Naukowe PWN.

Afuah, A. 2004. Business models. A strategic management approach. New York: McGraw-Hill/Irwin.

Arnold, D.; Isermann, H.; Kuhn, A.; Tempelmeier, H.; Furmans, K. 2008. Handbook logistics. Berlin: Springer.

Baden-Fuller, Ch.; Morgan, M. 2010. Business models as models, Long Range Planning 43(2-3): 156171. http://dx.doi.org/10.1016/j.lrp.2010.02.005

Bamford, C. 2010. The changing supply of logistics Services - a UK perspective, in D. Waters (Ed.). Global logistics: new directions in supply chain management. London, Philadelphia: Kogan Page. 
Blaik, P.; Bruska, A.; Kauf, S.; Matwiejczuk, R. 2013. Logistics system management. Relationships and trends. Warsaw: Polskie Wydawnictwo Ekonomiczne.

Blanchard, B. S. 2008. Logistics as an integrating system's function, in D. Taylor (Ed.). Logistics engineering handbook. Boca Raton, London, New York: CRC Press.

Brdulak, H. 2002. Outsourcing - strategic choice of the method of functioning of the market, Logistyka 32(4): 16-17.

Breiman, L.; Friedman, J.; Stone, C. J.; Olshen, R. A. 1993. Classification and regression trees. New York: Chapman and Hall/CR.

Burdzik, R.; Cieśla, M. 2006. Service outsourcing in transport - forwarding - logistics sector in Poland, Maszyny Dźwigowo - Transportowe 3-4: 32-37.

Casadesus-Masanell, R; Ricart, J. E. 2010. From strategy to business nodels and onto tactics, Long Range Planning 43: 195-215.

Casadesus-Masanell, R.; Zhu, F. 2013. Business model innovation and competitive imitation: the case of sponsor-based business models, Strategic Management Journal 34: 464-482. http://dx.doi.org/10.1002/smj.2022

Chesbrough, H.; Rosenbloom, R. S. 2002. The role of the business model in capturing value from innovation: evidence from Xerox Corporation's technology spin-off companies, Industrial and Corporate Change 11(3): 529-555. http://dx.doi.org/10.1093/icc/11.3.529

Corder, G. W.; Foreman, D. I. 2009. Nonparametric statistics for non-statisticians: a step-by-step approach. Hoboken: John Wiley. http://dx.doi.org/10.1002/9781118165881

Gattorna, J. 1998. Fourth party logistics: en route to breakthrough performance in the supply chain, in J. Gattorna (Ed.). Strategic supply chain alignment. Aldershot: Gower.

Gołębiowski, T.; Dudzik, T. M.; Lewandowska, M.; Witek-Hajduk, M. 2008. Business models of polish companies. Warsaw: Oficyna Wydawnicza SGH.

Grant, D. 2010. Using marketing and services strategies for logistics customer service, in D. Waters (Ed.). Global logistics: new directions in supply chain management. London, Philadelphia: Kogan Page.

Gudehus, T.; Kotzab, H. 2012. Comprehensive logistics. New York: Springer. http://dx.doi.org/10.1007/978-3-642-24367-7

Herrnstein, R. J.; Loveland, D. H.; Cable, C. 1976. Natural concepts in pigeons, Journal of Experimental Psychology Animal Behavior Processes 2: 285302. http://dx.doi.org/10.1037/0097-7403.2.4.285

Jabłoński, M. 2013. Shaping business models in the process of creation of enterprise value. Warsaw: Difin.
Johnson, M. W.; Christensen, C. M.; Kagermann H. 2008. Reinventing your business model, Harvard Business Review 86: 50-59.

Kotsiantis, S. B. 2007. Supervised machine learning: a review of classification techniques, Informatica 31(3): 249-268.

Lehmann, E. L. 2006. Nonparametrics: statistical methods based on ranks. New York: Springer-Verlag.

Lewis, R. J. 2000. An introduction to classification and regression tree (CART) analysis. San Francisco, CA: Harbor - UCLA medical center.

Loh, W. Y; Shih, Y. S. 1997. Split selection methods for classification trees, Statistica Sinica 7: 815-840.

Mahadevan, B. 2000. Business models for internetbased e-commerce: an anatomy, California Management Review 42(4): 55-69. http://dx.doi.org/10.2307/41166053

Mann, H. B.; Whitney, D. R. 1947. On a test of whether one of two random variables is stochastically larger than the other, Annals of Mathematical Statistics 18: 50-60. http://dx.doi.org/10.1214/aoms/1177730491

McGrath, R. G. 2012. When your business model is in trouble, Harvard Business Review 89(1-2): 96-98.

Nenonen, S.; Storbacka, K. 2010. Business model design: conceptualizing networked value co-creation, International Journal of Quality and Service Sciences 2(1): 43-59. http://dx.doi.org/10.1108/17566691011026595

Quinlan, J. R. 1993. C4.5: programs for machine learning. London: Morgan Kauffman.

Radziejowska, G. 2011. The development of logistic enterprise and competitive advantage, Zeszyty $\mathrm{Na}$ ukowe Politechniki Ślaskiej, Seria Organizacja $i$ Zarzadzanie 56: 253-275.

Rokach, L.; Maimon, O. 2008. Data mining with decision trees. Singapore: World Scientific Publishing Co. Pte. Ltd.

Rydzkowski, W. 2004. Logistic services. Poznan: Instytut Logistyki i Magazynowania.

Rydzkowski, W. 2011. Logistic services - theory and practice. Poznan: Wydawnictwo Biblioteka Logistyka.

Teece, D. 2010. Business models, business strategy and innovation, Long Range Planning 43(2-3): 172194. http://dx.doi.org/10.1016/j.lrp.2009.07.003

Wilcoxon, F. 1945. Individual comparisons by ranking methods, Biometrics Bulletin 1: 80-83. http://dx.doi.org/10.2307/3001968

Zysińska, M. 2013a. Concept of business models in the industry TFL and their classification, Autobusy, Technika, Eksploatacja, Systemy Transportowe 3: 611-624.

Zysińska, M. 2013b. Concept of the business model and its significance in the analysis of TFL branch enterprises, Transport Samochodowy 4: 23-53. 